\title{
SYNTACTIC ANALYSIS OF THE TRANSLATION OF THE INTERPRETATION OF THE NOBLE QUR'AN BY MUHAMMAD TAQIUDDIN AL-HILALI AND MUHAMMAD MUHSIN KHAN
}

\author{
Huriyah \\ (Fakultas Tarbiyah IAIN Syekh Nurjati Cirebon \\ Email: 61.huriyah@gmail.com)
}

Abstract: Muhammad Taqiuddin al-Hilali and Mubammad Mubsin Khan are distinguished translators of some Islamic books, such as, the interpretation of al-Qur'an, Sabih Al-Bukbari, and Al-Lu'lu' wa alMarjan into English. Selecting sūrah al-Qadr as a topic of syntactic analysis, the aim of this paper is to know syntactic rules in English translation used by the translators. The sūrah is selected because it contains important meaning. As an example, its third āyah states that laylah alQadr (the night of al-Qadr) is better than a thousand months'; it means that worshipping Allah in that night is better than worshipping Him a thousand months i.e., 83 years and 4 months. Analyzing the syntax of surah al-Qadr, the writer uses the rules of Transformational Grammar (TG).

Abstrak: Muhammad Taqiuddin al-Hilali dan Muhammad Mubsin Khan adalah penerjemah terkemuka atas beberapa buku Islam, seperti tafsir al-Qur'an, Sabih Al-Bukhari, dan Al-Lu'lu'wa al-Marjan. Dengan memilih sūrah al-Qadr sebagai topik dari analisis, tujuan penulisan makalah ini adalah untuk mengetahui aturan-aturan kalimat dalam penerjemahan bahasa Inggris yang dilakukan oleh penerjemah. Sūrah itu dipilih karena kandungan isinya yang sangat penting. Misalnya, dalam ayat ketiga sūrah itu dinyatakan bahwa laylah al-Qadr adalah malam yang lebib baik dari malam seribu bulan. Artinya, beribadah kepada Allah pada malam itu lebih baik dari beribadah seribu bulan, yaitu 83 tahun dan 4 bulan. Dalam menganalisis kalimat dari surah alQadr, penulis menggunakan aturan-aturan yang ada dalam Transformational Grammar (TG).

Keywords: syntactic analysis, surah al-Qadr, translation, interpretation, meanings, al-Qur'an. 
AL-QUR'AN is divine revelation from God (Allah the Almighty). The Qur'an, literally meaning. is "the recitation"; it is also central religious text of Islam. Muslims believe that Qur'an was verbally revealed from God to Muhammad through the angel Gabriel (Jibri) with different ways, time and conditions as guidance, response or answer of the problems faced by the prophet in a certain time, gradually over a period of approximately 23 years, beginning on 22 December $609 \mathrm{CE}$, when the prophet of Muhammad was 40 years old, and concluding in $632 \mathrm{CE}$, the year of his death. Qur'anic chapters are called sürah (single) or suwar (plural) and verses called ayyah (single) or ayät (plural). It contains 114 sürah and about 6.666 ayah with different lengths which is starting with sürah al-Fatihah and concluding with sürah al-Nas. Every sürah consists of some àyät, which is the longest sürah with 286 ayjat is surrah al-Baqarah and the shortest surab has only three àyät, i.e., sürab al-Kauthar.

Muslims regard the Qur'an as the most important miracle of Muhammad, a proof of his prophethood, and the culmination of a series of divine messages that started with the messages revealed to Adam and ended with Muhammad. They also believe that Qur'an is the holy book of Muslims all over the world. Muslims need Qur'an as guidance of their life in the world and in the here after. Everybody knows that language revealed and used in Qur'an is Arabic, ${ }^{1}$ as it stated in surah alZukhruf (43): 3

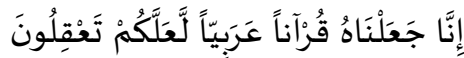

That is, Verily, we have made it a Qur'an in Arabic that you may be able to understand (its meanings and its admonitions).

Based on the ayah, it can be understood that Qur'an has revealed and has to be read by muslims in Arabic language, but not all people can comprehend the meanings and contents of it. So that, Qur'an needs to be translated into other languages, such as Bahasa Indonesia and English.

The translation term is the process of changing of speech or writing from one language to another with the aim to express

'See Jaib Najhan, "Pengertian Al-Qur'an Kitab Suci Ummat Islam". bttp:/ / jaibnajhan.blogspot.com/2012/12/pengerian-alQuran-kitab-ummat.html. Accessed on August 21 2014. 
the meaning of writing or speech in different language. The translation of holly Qur'an will be comprehended well if the translator understands the rules of source language and target language, such as grammar, semantics, morphology, and syntax.

Syntax is one of linguistics branches. It studies of how words can be put together to produce the well formed sentences of a language. Relation to this, the writer only focused on syntactic analysis of surah al-Qadr translation in the interpretation of the meanings of the Noble Qur'an in the English language by Muhammad Taqiuddin al-Hilali and Muhammad Muhsin Khan. In syntactic analysis of sürah al-Qadr translation the writer will use the rules of "transformational grammar" (TG).

\section{Biography of Both Translators}

The first translator, Al-Hilali, was born in the year 1311 $(\mathrm{AH})$ in a village called Al-Fidah in a valley near Sajalmasah in Morocco (North Africa). His grandfather migrated to this place from Al-Qairawan (Tunis), a long time ago. He was a person endued with religious knowledge and so was his father and so was family. Al-Hilali belongs to the family of Husain bin Ali the family of prophet Muhammad. His real name is Muhammad Taqiuddin, his kunyah is Abu Shakib. ${ }^{2}$

Al-Hilali memorized the Qur'an while a boy of 12 years then he studied Arabic grammar and tajwid and other Arabic knowledge of Prophet hadith. Al-Hilali also learned well the English and German languages. He traveled widely all over the world in search of knowledge (India, Iraq, Egypt, Saudi Arabia, etc). He worked as a teacher in these countries. He got his secondary school education in Al-Qarawyyth University, completed his education in Egypt, and got his doctorate from the Berlin University (German). He worked in Bagdad University, as an assistant professor, then a professor. Lastly, he worked as a professor in the Islamic University Al-Madinah.

${ }^{2}$ For more detail about Al-Hilai's biography about his birth, name, education and his career, read Dar-us Salam Publications "Biography of Muhammad Taqi-ud-Din Al-Hilali : Translator of the Noble Qur'an" in http:/ / www.dar-ussalam.com/ authors/taqi-ud-din-bilali.html. 
Al-Hilali had wide spread experience in the field of preaching has written many books and had done many religious and good deeds. He was possessed with true Islamic monotheist faith and had been inviting people to this faith and used to reply back those who used to oppose this doctrine. He had a good way of tackling the problems with wisdom and knowledge, which made him reach a high place in the field of knowledge. He shared with Muhammad Muhsin Khan in the translation of the meanings of the interpretation of the Qur'an and Sabih AlBukhari and the book Al-Lu'lu' wa al-Marjan into the English language during the period of his stay at the Islamic University al-Madinah al-Munawarah. He died in the year 1408 Hijrah.

The second translator, Muhammad Muhsin Khan, was born in the year $1345 \mathrm{H}$ (1927) in Qosur, a city of Punjab province, Pakistan. His grandfathers emigrated from Afghanistan escaping from the wars and ribal strifes. Muhammad Muhsin belongs to the famous Afghanis tribe Al-Khoaskhi Al-Jamandi. The residence place of his tribe was the valley of South East Afghanistan, the city of Kandhar.

Khan had most of his education in that city, then he continued his education till he gained degree in medicine and surgery from the University of Punjab, Lahore. He worked in the university hospital in Lahore, after that he traveled to England and stayed there for about four years, where he got the diploma of chest disease from the University of Wales. Then he worked in the ministry of health, in the Kingdom of Saudi Arabia. He came during the period of late King Abdul Aziz alSaud. He stayed in the Ministry of Health for about 15 years, most of that period was in Al-Ta'if, where he worked as the director of El-Sadad Hospital for the Chest Disease, then he moved to Al-Madinah, where he worked as a chief of the Department of Chest Disease in the King's Hospital. Then lastly, he worked as Director of Islamic University Clinic, AlMadinah.

Khan shared with Al-Hilali in the translation of the meanings of the abädith of the book Șabih al-Bukhäri and the book Al-Lu'lu' wa al-Marjān and the meanings of the interpretation of the Noble Qur'an into the English. 


\section{The Nature of Translation}

The word translation derives from the Latin translatio (which itself comes from trans and fero, the supine form of which is Latin, together meaning "to carry across" or "to bring across". 3 Translation in general can be classified into three types: 1) Intralingual, that is an interpretation of verbal signs by means of other signs of the same language; 2) Interlingual, that is an interpretation of verbal signs by means of some languages; and 3) inter semiotic translation, that is an interpretation of verbal sign system. ${ }^{4}$ The second type of translation is used by Al-Hilali and Khan in translation of the meanings of the Noble Qur'an.

The meaning of translation process, according to Robert, goes through three stages. ${ }^{5}$ The first stage consists of the analysis of the source text, the goal of which is thorough comprehension of the message it intends to convey. This stage involves not only recognition of the words and their meaning and of the relationship between them, but also grasping the meaning that underlies the words and understanding exactly what is being referenced to. The second stage involves transferring the source text message into the target language. It should be borne in mind that the product of this second stage is not considered the final one but in translation draft, which is still far from being perfect from the point of view of both accuracy of content and of appropriateness of style. The third stage of translation process is revision. At this point translator checks the target text against the source text to ensure that there are no omission, or addition or even meaning distortion. Moreover, the translator may review the translation to ensure that it is appropriate for the function it is expected to fulfill.

3See the Christopher Kasparek, "the translator's endless toil, P.83" (bttp:/ / en.wikipedia.org/wiki/ translation \#cite note 52), accessed June 27th 2013.

4Roman Jacobson, "On Linguistic Aspect of Translation", in Rainer Sechulte and John Bigunet (Eds), Theories of translation: An Anthology of Essay from Dryden to Derrida (Chicago: The University of Chicago Press, 1992).

5Roda P Robert, "Translation", in Robert B. Kaplan (ed.), The Oxford Handbook of Applied Linguistics (Oxford: Oxford University Press, 2002), 4334. 
Relation to this, Venuti believes that may final written translated text then can be judged successful, ${ }^{6}$ only when it reads fluently, it gives the appearance that is not translated, it is original, and it is transparently reflects the foreign author's intention and essential meaning of the foreign text. In addition, translator's performance can also be gauged from the translation text that he produced. The success of translating text because translator has the ability about the target language and sousce language. This understanding about ability is further supported by Makmur that ability constitutes capability of perform an activity as the result of heredity and training. ${ }^{7}$

Nida and Taber explain that the translation generally proceeds in the following phases. Firstly, analyzing, in which the surface structure, i.e., the message of given text in a language is analyzed in terms of the grammatical relationship, and the meaning of the words and combinations of the words, Secondly, transferring, in which the analyzed material is transferred in the mind of translator from language A to language B. Thirdly, restructuring, in which the transferred material is restructed in order to make the final message fully acceptable in receptor or target language. ${ }^{8}$ Thus, it can generally be understood that translation is the process of changing of speech or writing from one language to another with aim to express the meaning of writing or speech in different language.

\section{Syntax in English Language}

Syntax is the branch of descriptive linguistics that observes composition and words relation in the form of phrase and sentence. Syntax may be roughly defined as the principles of arrangement of the constructions formed by the process of derivation and inflection (words) into larger constructions of

'See Lawren Venuti (Ed), Rethinking Translation: Discourse, Subjectivity, Ideology (London: Rout ledge, 2004), 4.

'Ilzamuddin Ma'mur, The Ability to Translate Informative Text From Indonesian into English, Dissertation (Jakarta: State University of Jakarta, 2008), 7.

${ }^{8}$ See Eugene A. Nida and Charles R. Taber, The Theory ad Practice of Translation (Leiden: E.J. Brill, 2001), 34. 
various kinds. ${ }^{9}$ Syntax also can be described how words are combined to form phrases, clauses and sentences. ${ }^{10}$

Relation to this, Gleason and Ratner state that syntax is the study of how words can be put together to produce the well formed sentences of a language. ${ }^{11}$ Consider a sentence such as John loves Mary. This sentence consists of a linear string of words John, loves, and Mary. However, we cannot combine these words randomly in English without changing the meaning of reducing grammatical acceptibility. Consider the following sentences.
a. John loves Mary
b. Mary loves John
c. Loves John Mary

From these sentences can be concluded that the first and second sentences are grammatical, while the third sentence is ungrammatical.

\section{Knowledge of Transformational Grammar}

Grammar is a device of some sort for producing the sentences of the language under analysis, namely with transformational grammar. ${ }^{12}$ The grammar of language consists of rules that will generate/produce sentences grammatically acceptable to native speakers.

The sentences actually uttered are only a small proportion of the unlimited number of sentences that can be uttered in the language. A speaker's competence would enable him to produce a sentence like: "Prince Diponegoro telephoned president Soeharto to invite him to dinner in Gua (cave) Selarong”. This is a concrete English sentence but it would never have been actually used except to illustrate the concept of competence here.

${ }^{9}$ Read Gleason, H.A, An Introduction to Descriptive Linguistics (New York: Holt, Rinehart and Winston, 1961), 128.

${ }^{10}$ Read Keith Brown and Jim Miller, Concise Encyclopedia of Syntactic Theories (Great Britain: Cambridge University Press, 1996), 85.

${ }^{11}$ See Jean Berko Gleason and Nan Bernstein Ratner, Psycholinguistics (USA: Holt, Rinehart and Winston, 1998), 5.

12David Crystal, The Cambridge Encyclopedia of Language (Cambridge: Cambridge University Press, 2000), 97. 
Transformational grammar shows that there are certain kinds of relationship between sentences that can not be shown by immediate constituents analysis, for example:

1. Pele kicked the ball. (Noun $+\mathrm{V}+$ Det $+\mathrm{N}$ )

2. The ball was kicked by Pele (Det $+\mathrm{N}+$ Aux $+\mathrm{V}+$ Prep $+\mathrm{N}$ )

In immediate constituents (IC) analysis these two sentences would be described as two different sentences with different sequences of elements. Transformational grammar (TG) regards passive sentences as being transformed from active sentences. The subject (Pele) and object (the Ball) in (1) have changed places in (2) where the ball is the subject and Pele is the agent preceded by by. Transformation $=$ being changed from one form into another.

Rules in transformational grammar (TG). "The man may bring a gift"

$\begin{array}{ll}\text { S (Sentence) } & \text { S (Sentence) } \\ \text { Rule 1 } & \text { NP }+ \text { VP } \\ \text { Rule 2 } & \text { NP }+ \text { Verb }+ \text { NP } \\ \text { Rule 3 } & \text { Det }+\mathrm{N}+\text { Verb }+ \text { Det }+\mathrm{N} \\ \text { Rule } 4 & \text { Det }+\mathrm{N}+\text { Aux }+ \text { main Verb }+ \text { Det }+\mathrm{N} \\ \text { Rule } 5 & \text { The }+\mathrm{N}+\text { Aux }+ \text { main verb }+\mathrm{a}+\mathrm{N} \\ \text { Rule 6 } & \text { The }+ \text { man }+ \text { Aux }+ \text { main verb }+\mathrm{a}+\text { gift } \\ \text { Rule } 7 & \text { The }+ \text { man }+ \text { may }+ \text { main verb }+\mathrm{a}+\text { gift } \\ \text { Rule } 8 & \text { The }+ \text { man }+ \text { may }+ \text { bring }+\mathrm{a}+\text { gift }\end{array}$

\section{The Holy Qur'an}

The word "Qur'an" a verbal noun, is equivalent in meaning to "Qira'ab" as both came from the verb "Qira' $a$ " which means "to read". In the meaning of literally, Qur'an means as "a reading or reciting". Qur'an could be defined as Allah's word which were revealed in Arabic in a rhythmical form to Prophet Muhammad. Its recitation is used in acts of worship and its smallest chapter (sürab) is of a miraculous nature. The prophet's divinely inspired statements which were by his followers are generally referred to as hadits. For example the prophet's companion, Umar ibn al-Khattab, reported that he once said "verily, deeds are (judged) by their intentions". However in 
some of his statements, the Prophet attributed what he said to Allah.

The Qur'an, however, is not the same as hadith qudsi for a number of reasons. Firstly, the Qur'an is from Allah both in its wording and in its meaning; while in badith qudsi, its meaning is from Allah but its wording was the prophet's. Secondly, Allah challenged the Arabs and mankind in general to produce even a chapter equivalent to one of the Qur'an's chapters, and their inability to do so proves its miraculous nature. This is not so in hadits qudsi. Third, the recitation of the Qur'an is used in saläh (prayer) and is itself considered a form of worship.

The Qur'an introduces itself with some features and characteristics. One of them that al-Qur'an is the book that is its authenticity always guaranteed and looked after by Allah, ${ }^{13}$ as it is stated in surah al-Hijr (15): 9

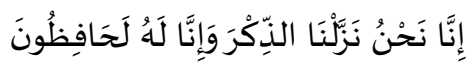

Verily, we, it is We who have sent down the dhikr (i.e., the Qur'an) and surely, we will guard it (from corruption).

Al-Qur'an also became truth evidence of prophet Muhammad, but the main function of al-Qur'an is as guidance for human being in the world. Al-Qur'an revealed in the time about twenty two years and two months, and twenty two days.

\section{Sūrah Al-Qadr: Its Asbāb al-Nuzūl and Translation}

In history, there is an expression that prophet Muhammad dream to see the Umayyads occupy and control the pulpit after the prophet death. By then the prophet was not happy because of this matter. Then the verse came in surrah al-Kawthar (108): 1 and al-Qadr (97): 1-5 to encourage the prophet (narrated by Tirmidhi and Al-Hakim and Ibnu Al-Hasan bin Ali).

In another history, there is an expression that prophet never mentions that one of the children of Israel fought using weapons fi sabil al-Läh, the quest for a thousand months. The muslims were amazed by the taste of the people struggle. So Allah revealed sürah al-Qadr (97): 1-5 which explain layl al-qadr 10.

13M. Quraish Shihab, Membumikan Al-Qur'an (Bandung: Mizan, 1996), 
that one night of al-qadr is better than the struggle of the Israelites during the 1000 months (narrated by Ibnu al-Hatim and al-Wahidi from Mujahid). Another meaning of the night of al-qadr has meaning that worshipping Allah in that night is better than worshipping Him a thousand months, i.e., eighty three years and four months. ${ }^{14}$

Surah al-Qadr consists of five àyat. The sürab is a part of the holy Qur'an that people usually recite in the prayer of taramin in the end of Ramadan month. In this point the writer will show about the surah Qadr and its translation as follows:

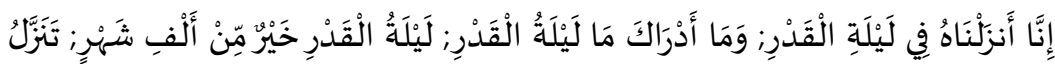

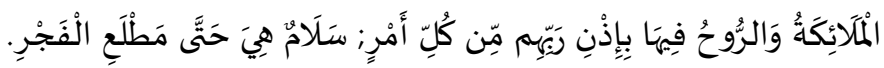

(1) Verily, we have sent it (this Qur'an) down in the night of al-qadr, (2) And what make you know what the night of al-qadr (Decree)? (3) The night of al-qadr is better than a thousand months. (4) There in descend the angels and the ruh by Allah's permission with all decrees. (5) There is a peace until the appearance of down

\section{The Syntactic Analysis of Sürah Al-Qadr Translation}

The first ayyah: Verily, we have sent it (this Qur'an) down in the night of al-qadr (decree).

It is a complete sentence. It is called a main clause. If we see the rules of $\mathrm{TG}$, the first rule of sentence usually consists of noun phrase (NP) plus verb phrase (VP). See this sentence, it starts with adverb, like the word 'verily'. The stem of 'verily' is from 'very' adding 'ly'. It is called adverb, after adverb then followed by NP plus VP. The last rule of this sentence consists of adverb (verily) plus NP (we) plus auxiliary (tense present: have) plus past participle (sent) plus determiner (this) plus noun (Qur'an) plus adjective (down) plus preposition (in) plus determiner (the) plus noun (night) plus preposition (of) and plus noun (al-qadr).

The second ayyah: And what make you know what the night of al-qadr (decree)?

${ }^{14}$ Read Muhammad Taqiuddin Al-Hilali and Muhammad Muhsin Khan, Interpretation of The Meanings of The Noble Qur'an in The English Languege. (Riyadh: Darussalam, 1999), 809. 
It is a point of the first ayah. It is called a sub clause, namely adjective clause of the first ayah, that modifies the head noun it (al-Qur'an) in the first ayah. This clause starts with conjunction (and), followed with a subordinator (what), that has function as a pronoun of it (al-Qur'an) and VP that contains auxiliary (tense present: will) plus main verb (make) plus NP (you and know). The next constituents starts with subordinator (what) followed with NP. NP here consists of determination (the) and noun (night), then followed with prepositional phrase (PP). PP consists of preposition (of) and noun (al-qadr) plus auxiliary (present, is). Concerning with all the constituents of this clause, we can analyze with last rule of TG consists of conjunction (and), plus subordinator (what), plus auxiliary (tense present: will), plus main verb (make), plus pronoun (you) plus main verb (know), plus subordinator (what), plus determination (the), plus noun (night), plus preposition (of), plus noun (al-qadr) and plus auxiliary (present : is).

The third ayyah: The night of Al-Qadr is better than a thousand months.

From the third sentence above, we know that it is a sentence that is the answer of the second ayah, i.e., what the night of alqadr is? The sentence starts with NP plus PP and plus VP. The NP consists of determination (the) and noun (night). Then after NP followed with PP, the PP consists of preposition (of) and noun (al-qadr). After PP followed with VP, VP consists of Adjective Phrase. (AP), AP consists of adjective comparative degree (better than) plus NP, NP followed with determination (a) and noun (thousand months), the suffix s after months indicates plural in this sentence.

If we analyze with using last TG, the sentence consists of determiner (the), plus noun (night), plus preposition (of), plus adjective comparative degree (better than), plus determiner (a) and plus noun plural (thousand months).

The fourth àyah: There in descend the angels and the rub by Allah's permission with all decrees.

In the fourth ayah of surah al-Qadr, this sentence begins with an adverb (there), plus prepositional phrase (in and descend) plus NP (the angles). The coordination or conjunction (and) 
have significant function if it coordinates to the sentences or ayahs before. Conjunction (and) coordinates the word angles and the ruh.

In this sentence, the use of preposition (by) precedes before NP, NP using noun (Allah's permission), then followed with PP, $\mathrm{PP}$ consists of preposition (with) and NP consists of determiner (all) and noun plural (decrees). The last analysis of TG consists of adverb (there), plus preposition (in) plus verb (descend), plus determiner (the), plus noun plural (angles), plus conjunction (and), plus determiner (the) plus noun ( Ruh), plus preposition (by), plus noun (Allah's permission), plus preposition (with), plus determiner (all), plus noun plural (decrees).

\section{The fifth àyah: There is a peace until the appearance of down}

Based on the sentence above, we know that the sentence "there is peace until the appearance of down " begins with NP that consists of noun (there) and VP that consists of auxiliary (present: is) and noun (peace). Then it followed with conjunction (until) and NP. The NP consists of determiner (the) and noun (appearance). After NP followed with PP. The PP consists of preposition (of) and plus noun (down).

If we analyze the last sentence with the last rule of TG it will consist of NP (there), plus auxiliary (present: is), plus noun (peace), plus conjunction (until), plus determiner (the), plus noun (appearance), plus preposition (of), and plus noun (down).

\section{Conclussion}

Based on the syntactic analysis of sürah al-Qadr translation in interpretation of the meanings of the holy Qur'an in the English language by al-Hilali and Khan related to the theory of syntax based on the rules of TG as explained above, it can be generally concluded that there are five sentences patterns of the sentence in English translation of surrah al-Qadr as follows:

The first translation consists of Subject $=$ adverb $+\mathrm{NP}+$ VP. The second translation consists of Subject $=$ Conjunction + $\mathrm{NP}+\mathrm{VP}+$ subordination $+\mathrm{NP}+\mathrm{PP}$. The third translation consists of Subject $=\mathrm{NP}+\mathrm{PP}+\mathrm{VP}$. The fourth translation consists of Subject $=$ Adverb $+\mathrm{PP}+\mathrm{NP}+$ conjunction $+\mathrm{NP}$ 
$+\mathrm{PP}+\mathrm{PP}$. The fifth translation consists of Subject $=\mathrm{NP}+\mathrm{VP}$

+ conjunction $+\mathrm{NP}+\mathrm{PP}$.

It can also be concluded that English translation of sürah alQadr contains some complex sentences and conjunctions that relating one sentence to another sentence.

\section{Bibliography}

Al-Hilali, Muhammad Taqi-ud-Din and Khan, Muhammad Muhsin.1999. Interpretation of The Meanings of The Noble Qur'an in The English Languege. Riyadh: Darussalam.

Brown, Keith and Miller Jim. 1996. Concise Encyclopedia of Syntactic Theories. Great Britain: Cambridge University Press.

Crystal, David. 2000. The Cambridge Encyclopedia of Language. Cambridge: Cambridge University Press.

Darul Hadits. 2013. "15 ${ }^{\text {th }}$ century (1400 H-1499 H) -1345 H Dr. Muhammad Muhsin Khan". (Online). http:// www.defenderafsunnah.com/ home/scholars/majorulama/2830-15th-century-1400h-1499h-1345h-dr-muhammadmubsin-khan. Accessed on June 28 2013.

Dar-us Salam Publications. 2013. "Biography of Dr. Muhammad Taqi-ud-Din Al-Hilali. Translator of the Noble Qur'an". (Online). http://www.dar-ussalam.com/authors/taqi-ud-dinbilali.btml. accessed on June 27th 2013.

Gleason, Jean Berko \& Ratner, Nan Bernstein. 1998. Psycholinguistics: Second Edition. USA: Holt, Renehart and Winston.

Gleason, H. A. 1961. An Introduction to Descriptive Linguistics. New York: Holt, Renehart and Winston.

Jacobson, Roman. 1992. On Linguistic Aspect of Translation. In Rainer Schultle and John Bigunet (eds), theories of translations: An Authology of Essays from Dryden to Derrida. Chicago: The University of Chicago Press.

Jaib Najhan. 2014. "Pengertian Al-Qur'an Kitab Suci Ummat Islam". (Online). http://jaibnajhan.blogspot.com/2012/12/pengertianalquran/kitab/ ummat.html. accessed on August 21 2014. 
Kasparek, Christopher. 2013. “The Translator's Endless Toil”. (Online). http:/ / www.wikipedia.org/wiki/ translation \#cite note 52. accessed on June $27^{\text {th }} 2013$.

Ma'mur, Ilzamudin. 2008. The Ability to Translate Informative Text From Indonesian into English. Dissertation, Jakarta: State University of Jakarta.

Nida, Augene Albert and Charles R. Taber. 2001. The Theory and Practice of Translator. Leiden: E.J. Brill.

Roberts, P. Roda. 2002. "Translation", in Robert B, Kaplan, ed., The Oxford Handbook of applied Linguistics. Oxford: Oxford University Press.

Syihab, M. Quraish. 1996. Membumikan Al-Qur'an. Bandung: Mizan.

Venuti, Lowrence (Ed). 2004. Rethinking Translation: Discourse, subjectivity, Ideology. London: Rutledge.

Yule, George. 2006. The study of Language: Third Edition. New York: Cambridge University Press. 